\title{
Kemandirian Pengadilan Dalam Proses Penegakan Hukum Pidana Menuju Sistem Peradilan Pidana Yang Bebas Dan Bertanggung Jawab
}

\author{
Rusli Muhammad \\ Fakultas Hukum Universitas Islam Indonesia \\ J1. Tamansiswa No. 158 Yogyakarta \\ rusli@fh.uii.ac.id
}

\begin{abstract}
This research discusses problems on judicial independence in relation to the effort the criminal law enforcement. There are two basic problem in this study, first, how judicial independence in the context of criminal law enforcement is, what the influential factors behind it are and what implication causes are. Second, how the effort made for the reformation of judicial independence toward independence and responsible criminal judicial systems. The approach used for this reseaach is socio legal studies and systems appoarch with philosophical appoach as a complement. Data were collected by interview and distributing questioners, data collected were analyzed using discriptive analytical methods. The law of the degree of judicial independence was caused by miscellanies internal and external factors. Internal factors aimed are factors in the body of system which directly interrelated with judicial system. Whereas external factors are factors which lie out side judicial system.
\end{abstract}

Key words: judicial independence, law enforcement, restructurisation, revitalization of judicial and reform to regulation

\begin{abstract}
Abstrak
Penelitian ini membahas persoalan sekitar kemandirian pengadilan dalam upaya penegakan hukum pidana. Ada dua masalah pokok yang menjadi fokus studi ini. Pertama, bagaimana kemandirian pengadilan dalam upaya penegakan hukum pidana , faktor-faktor apa yang memepngaruhi dan apa implikasinya terhadap penegakan hukum pidana. Kedua, bagaimana upaya penataan kemandirian pengadilan menuju sistem peradilan pidana yang bebas dan bertanggung jawab.

Pendekatan yang digunakan adalah pendekatan socio legal studies dan pendekatan sistem (system approach), dilengkapi pula dengan pendekatan filosofis. Adapun data-data dikumpulkan melalui tehnik wawancara dan kuesioner, kemudian dianalisis dengan tehnik analisa secara deskritif. Hasil penelitian menyimpulkan: rendah dan lemahnya kemandirian pengadilan disebabkan karena pengaruh dari berbagai faktor baik faktor internal maupun faktor eksternal. Faktor internal adalah faktor yang muncul di dalam tubuh dan berkaitan langsung dengan lembaga peradilan. Adapun faktor eksternal adalah faktor-faktor yang berada di luar pengadilan.
\end{abstract}

Kata kunci: kemandirian pengadilan, penegakan hukum, restrukturisasi, revitalisasi pengadilan dan reformasi peraturan huikum. 


\section{Pendahuluan}

Kebijakan perlindungan masyarakat (Social Defence Policy) dapat diwujudkan melalui usaha-usaha penanggulangan kejahatan sampai pada akar-akarnya. Selama ini berbagai bentuk reaksi dan respon sosial dapat dilakukan untuk menanggulangi kejahatan yaitu dengan cara penegakan hukum pidana/penal. Sebenarnya penanggulangan kejahatan dengan menggunakan hukum pidana/penal bukanlah satu-satunya cara, melainkan dapat pula dengan menggunakan cara atau kebijakan lain yang sifatnya non-penal, misalnya melalui jalur pendidikan, penyantunan sosial, peningkatan taraf kesehatan masyarakat dan lain-lainnya. Adanya jalur non-penal ini karena dianggap bahwa penggunaan hukum pidana atau penegakan hukum pidana bukan satu-satunya cara yang ampuh dalam menanggulangi kejahatan. Hal ini wajar karena pada hakikatnya kejahatan itu merupakan masalah kemanusiaan dan masalah sosial yang tidak dapat diatasi semata-mata dengan hukum pidana. ${ }^{1}$

Menetapkan kebijakan non-penal dalam usaha penanggulangan kejahatan adalah suatu isyarat bahwa penegakan hukum pidana dalam rangka penanggulangan kejahatan itu, kemampuannya terbatas dan bukan satu-satunya tumpuan harapan. Meskipun demikian, penegakan hukum pidana tetap merupakan prioritas utama yang keberhasilannya tetap diharapkan, lagi pula pada bidang penegakan hukum inilah dipertaruhkan makna negara berdasarkan atas hukum. ${ }^{2}$

Penggunaan hukum pidana dalam proses peradilan pada hakikatnya merupakan penegakan hukum pidana itu sendiri, dan ini merupakan pula bagian dari politik kriminal yaitu suatu kebijakan yang rasional guna penanggulangan kejahatan dengan tujuan akhirnya kesejahteraan umat manusia. Hukum pidana tidak dapat beroperasi dengan sendirinya. Hukum itu hanya dapat beroperasi melalui orang. Inipun dibutuhkan peraturan-peraturan yang memungkinkan orang tersebut dapat melaksanakan hukum pidana itu, yaitu berupa peraturan hukum acara. Selain ketentuan hukum acara diperlukan pula lembaga Pengadilan lengkap dengan petugas-petugasnya guna memberi wadah pelaksanaan hukum pidana itu.

Dalam sistem hukum kita, Pengadilan ditempatkan sebagai badan yang mandiri terlepas dari kekuasaan mana pun. Hal ini terlihat pada Pasal 1 UU No. 14 Tahun

\footnotetext{
${ }^{1}$ Barda Nawawi Arief, Beberapa Aspek Kebijakan Penegakan dan Pengembangan Hukum Pidana, Bandung, Citra Aditya Bakti, 1998, hlm. 33.

${ }^{2}$ Bambang Peornomo, Orientasi Hukum Acara Pidana Indonesia, Yogyakarta, Amerta Buku 1984, hlm. 30.
} 
1970 sebagaimana yang telah dirubah dengan UU No 4 tahun 2004 menyebutkan, bahwa “Kekuasaan Kehakiman adalah kekuasaan negara yang merdeka untuk menyelenggarakan peradilan guna menegakkan hukum dan keadilan berdasarkan Pancasila, demi terselenggaranya Negara Hukum Republik Indonesia". Lebih lanjut dalam pasal berikutnya dikatakan, "Penyelenggaraan kekuasaan kehakiman.... diserahkan kepada Badan-badan peradilan.... dengan tugas pokok untuk menerima, memeriksa dan mengadili serta menyelesaikan setiap perkara yang diajukan kepadanya". (Pasal 2 ayat 1 ).

Kekuasaan kehakiman yang merdeka, sebagaimana disebutkan dalam Pasal 24 ayat 1 UUD 1945, harus dilakukan oleh Mahkamah Agung dan lain-lain Badan kehakiman menurut undang-undang. Penegasan UUD ini menunjukkan bahwa Mahkamah Agung dan badan-badan kehakiman lainnya merupakan pelaksana seluruh kegiatan penyelenggaraan peradilan yang dilakukan dalam wilayah Indonesia. Tidak saja sebagai penyelenggara tetapi Barda Nawawi Arief mengusulkan agar Mahkamah Agung ditetapkan sebagai "Pejabat Pengendali". ${ }^{3}$ Sejalan dengan itu menurut Bambang Poernomo, kekuasaan kehakiman merupakan identitas yudikatif yang harus terlepas dari pengaruh kekuasaan pemerintah (eksekutif) dan kekuasaan perwakilan rakyat (legislatif) untuk menghindarkan kekuasaan negara yang tak terbatas. ${ }^{4}$ Dengan demikian dapat dimengerti bahwa kekuasaan kehakiman adalah kekuasaan yang bebas, mandiri dalam menyelenggarakan peradilan yang dilaksanakan oleh badan-badan peradilan, di bawah kendali Mahkamah Agung.

Sebagai lembaga yang melaksanakan kekuasaan kehakiman, maka pengadilan ini pun merupakan lembaga yang bebas dan merupakan suatu syarat dalam suatu masyarakat di bawah Negara Hukum. Kebebasan demikian mengandung didalamnya kebebasan dari campur tangan dari badan-badan lainnya baik eksekutif maupun legislatif.

Kebebasan yang dimiliki Pengadilan tidak lain adalah suatu kemandirian yang sangat diperlukan (indispensable) dan merupakan "Conditio Sine Qua non" karena selain menunjukkan bahwa negara ini adalah Rechtstaat juga menunjukkan akan adanya jaminan terselenggaranya peradilan yang independen guna menegakkan hukum yang berintikan keadilan, jauh dari kepemihakan.

${ }^{3}$ Sri Soemantri M, "Kemandirian Kekuasaan Kehakiman Sebagai Prasyarat Negara Hukum, Tinjauan HistorisYuridis Atas Perinsip dan Manifestasinya”. Makalah Seminar 50 Tahun Kemerde-kaan Kekuasaan Kehakiman di Indonesia, FH UGM Yogyakarta tgl 26 Agustus 1995, hlm 14. 
Kekuasaan kehakiman yang merdeka sebagaimana disebutkan dalam Pasal 24 ayat (1) UUD 1945 harus dilakukan oleh Mahkamah Agung dan lain-lain badan kehakiman menurut undang-undang. Penegasan UUD ini menunjukkan bahwa Mahkamah Agung dan badan-badan kehakiman lainnya merupakan pelaksana seluruh kegiatan penyelenggaraan peradilan yang dilakukan dalam wilayah Indonesia. Tidak saja sebagai penyelenggara tetapi Barda Nawawi Arief mengusulkan agar Mahkamah Agung ditetapkan sebagai "Pejabat Pengendali." ${ }^{5}$ Sejalan dengan itu menurut Bambang Poernomo, kekuasaan kehakiman merupakan identitas yudikatif yang harus terlepas dari pengaruh kekuasaan pemerintah (eksekutif) dan kekuasaan perwakilan rakyat (legislatif) untuk menghindarkan kekuasaan negara yang tak terbatas. ${ }^{6}$ Dengan demikian dapat dimengerti bahwa kekuasaan kehakiman adalah kekuasaan yang bebas, mandiri dalam menyelenggarakan peradilan yang dilaksanakan oleh badan-badan peradilan, di bawah kendali Mahkamah Agung.

Kebebasan yang dimiliki Pengadilan tidak lain adalah suatu kemandirian yang sangat diperlukan (indispensable) dan merupakan “Conditio Sine Qua non" karena selain menunjukkan bahwa negara ini adalah Rechtstaat juga menunjukkan akan adanya jaminan terselenggaranya peradilan yang independen guna menegakkan hukum yang berintikan keadilan, jauh dari kepemihakan.

Secara konstitusional maupun berdasarkan undang-undang telah terdapat jaminan terhadap kemandirian atau kebebasan pengadilan, yakni mandiri dalam menjalankan kekuasaannya, dalam arti bebas dari pengaruh kekuasaan pemerintah terutama dalam menyelenggarakan peradilan dalam rangka penegakan hukum. Dalam kenyataannya kemandirian Pengadilan ini terkadang dicampuri oleh kekuasaan lain, seperti disebutkan oleh Sri Soemantri dalam makalahnya bahwa “...terjadi kasus-kasus yang menunjukkan adanya pengaruh ekstra yudisial terhadap kekuasaan kehakiman. Contoh-contoh yang sempat menimbulkan perbincangan dalam masyarakat adalah kasus Marsinah dan kasus Jayapura". ${ }^{7}$ Lebih lanjut Sri Soemantri menjelaskan bahwa:

“Kasus buruh Marsinah yang "melibatkan" oknum aparat keamanan ternyata menampilkan orang-orang lain dalam persidangan kasus tersebut. Pada waktu

\footnotetext{
${ }^{5}$ Muladi dan Barda Nawawi, "Ruang Lingkup Penegakan Hukum Pidana dalam Konteks Politik Kriminal" (Makalah Seminar Kriminologi, FH UNDIP Semarang tgl 11-13 November 1986), hlm. 1.

${ }^{6}$ Ibid

${ }^{7}$ Barda Nawawi Arief, "Beberapa Aspek Kebijakan Penegakan dan Pengembangan Hukum Pidana”, Bandung, Penerbit Citra Aditya Bakti, 1998, hlm. 33.
} 
kasus ini disidangkan, terdapat dugaan yang kuat para hakim yang mengadili tidak bebas lagi dalam melaksanakan tugas dan wewenangnya. Oleh karena itu para penasihat hukum yang mendampingi para terdakwa mengajukan banding dan kemudian kasasi". ${ }^{8}$

Gambaran adanya realitas yang demikian itu, sungguh disayangkan sebab turut campurnya kekuasaan lain dalam penyelenggaraan peradilan adalah inkonstitusionil dan bertentangan dengan undang-undang.

Kemandirian pengadilan ditentukan oleh berbagai faktor yang saling terkait, dan secara bergantian muncul sebagai pengaruh yang kuat di dalam menentukan kemandirian lembaga peradilan. Untuk itu, jika mengharapkan lembaga peradilan beriringan dan ikut bertanggung jawab di dalam mencapai tujuan negara, maka terlebih dahulu harus memperhatikan bebagai faktor-faktor yang berpengaruh itu.

Lembaga peradilan dalam proses peradilan pidana lebih cenderung tampak sebagai lembaga dependen (tergantung) daripada menjadi lembaga independen (mandiri) bagi upaya pendayagunaan hukum kearah terwujudnya kebenaran dan keadilan. Kecenderungan ini disebabkan karena berbagai peraturan hukum yang ada membatasi kebebasan itu. Kewenangan atau kekuasaan yang diberikan oleh undang-undang terhadap lembaga peradilan (yudikatif) adalah lebih sedikit dan tidak memperlihatkan kesamaan dan keseimbangan dengan kekuasaan eksekutif maupun legislatif, sehingga hukum menjadi disfungsional dalam mengintegrasikan kepentingan yang menjadi syarat kemandirian lembaga peradilan.

Kemandirian pengadilan cenderung melemah disebabkan pula karena organisasi kelembagaan yang telah ditentukan dalam peraturan hukum tidak mendukung mekanisme kerja sebagai lembaga terpadu dan mandiri, dan atau karena proses pelembagaan hukum yang tidak tepat sehingga lembaga-lembaga hukum hanya lebih mewujudkan kepemihakan atau tidak lebih sekedar menghasilkan keadilan formal dengan mengabaikan keadilan substansial. Selain itu karena politik hukum Indonesia menempatkan lembaga peradilan berada dalam posisi tidak bebas dan berada dalam kendali kekuasaan eksekutif (pemerintah) sehingga fungsi-fungsi dan aktivitas yang dijalankan tidak lebih dari kelanjutan kepentingan penguasa eksekutif. Sementara itu lemahnya kemandirian pengadilan cenderung pula dari aparat penegak hukum (Polisi, Jaksa dan Hakim) itu sendiri. Aparat penegak hukum dengan

${ }^{8}$ Bambang Peornomo, "Orientasi Hukum Acara Pidana Indonesia" (Yogyakarta :Penerbit Amerta Buku 1984) hal. 30. 
status kepegawaiannya sebagai pegawai negeri diharuskan loyal pada korps menyebabkan sulit mengambil keputusan yang berbeda dengan keinginan atasannya, hal ini didukung pula oleh masih berpengaruhnya budaya paternalistik dan tidak adanya check and balance serta pertanggungan jawab publik (public accountability).

\section{Rumusan Masalah}

Di dalam penelitian ini masalah yang diteliti adalah, pertama, bagaimana kemandirian pengadilan dalam upaya penegakan hukum pidana, faktor-faktor apa yang mempengaruhi dan apa implikasinyanya terhadap penegakan hukum pidana? Kedua, bagaimana upaya penataan kemandirian pengadilan menuju sistem peradilan pidana yang bebas dan bertanggungjawab?

\section{Metode Penelitian}

Penelitian ini mendasarkan pola dan cara kerja pada paradigma terpadu $\mathrm{u}^{9} \mathrm{yang}$ membagi dan membahas tingkatan realitas sosial secara integratif. Dengan paradigma terpadu, maka Kemandirian Pengadilan harus dipandang sebagai persoalan khusus yang muncul tidak semata-mata kekuatan normatif atau jelmaan birokrasi kekuasaan, tetapi muncul sebagai suatu proses yang saling mempengaruhi diantara berbagai satuan-satuan sosial yang ada.

Penelitian ini selain menggunakan pendekatan positivisme ${ }^{10}$ menggunakan pula pendekatan interaksi simbolik ${ }^{11}$ Pendekatan positivisme digunakan untuk memahami apa dan bagaimana seharusnya hukum mengatur kemandirian lembaga peradilan. Sementara pendekatan interaksi simbolik digunakan untuk memahami proses stimulan dan respon, kompetensi komunikatif dam tindakan-tindakan sosial yang ditempatkan dalam simbol-simbol manusia dalam kerangka kerja lembaga peradilan pidana.

\footnotetext{
${ }^{9}$ Paradigma terpadu adalah sebuah paradigma yang dikemukakan oleh George Ritzer sebagai salah suatu alternatif pilihan dari paradigma sosiologi yang telah ada. Paradigma terpadu menurut George Ritzer akan menerangkan secara komprehensif berbagai tingkat realitas sosial, baca dalam, Goerge Ritzer, Sosiologi Ilmu Pengetabuan Berparadigma Ganda, Terjemahan, Cetakan kedua, Jakarta, Rajawali Pers, 1992, hlm. 169.

${ }^{10}$ Positivisme menurut H. Neong Muhadjir bertolak dari premis premis seperti; perilaku semua orang itu pada dasarnya sama, bahwa yang kompleks itu dapat dianalisis menjadi bagian yang lebih elementer; baca dalam, $\mathrm{H}$. Noeng Muhadjir, Metodologi Pene-litian Kuantitaitf (Edisi ke-III), Yogya-karta, Rakesarasin, 1996, hlm. 136.

${ }^{11}$ Pendekatan ini berasumsi bahwa pengalaman manusia ditengahi oleh penafsiran. Obyek, orang, situasi, dan peristiwa tidak memiliki pengertiannya sendiri, sebaliknya pengertian itu diberi-kan untuk mereka, baca dalam Lexy J. Moleong, Metodologi Peneli-tian Kualitatif, Bandung, PT. Remaja Rosdakarya, Cetakan ke-10, 1999, hlm. 10.
} 
Jenis data baik data primer maupun data sekunder yang akan dikumpulkan di dalam penelitian ini dikelompokkan ke dalam 3 (tiga) kategori yaitu : (1) data tentang materi hukum yang meliputi; masalah legitimasi, kekuasaan dan peran lembagalembaga peradilan; bentuk, proses dan tata kerja lembaga peradilan pidana dan bentuk pengawasan lembaga peradilan; (2) data tentang penyelenggaraan peradilan meliputi; model dan prosedur-prosedur yang dipilih; instrumen keras maupun lunak; pengaruh-pengaruh kekuasaan dan kekuatan internal dan eksternal; budaya hukum bagi para penyelenggara peradilan. (3) data tentang respon penegak hukum dan potensi-potensi eksternal masyarakat sebagai sarana potensial terbentuknya kemandirian lembaga peradilan, yang meliputi; tanggapan tentang adanya pemisahan atau pembagian kekuasaan eksekutif, yudikatif dan legislatif; tanggapan tentang kemandirian lembaga-lembaga peradilan dalam upayanya melakukan penegakan hukum; dan respon tentang propesionalisme serta mentalitas para penegak hukum.

Analisa terhadap data yang diperoleh dilakukan dengan cara kualitatif. Analisa kualitatif ini diperlukan untuk menjelaskan suatu rangkaian kaitan-kaitan kausal tentang fenomena tertentu, yang bersifat kompleks dan sulit diukur secara pasti.

\section{Hasil Penelitian dan Pembahasan}

Menurut Soerjono Soekanto, ${ }^{12}$ secara konsepsional inti dan arti penegakan hukum terletak pada kegiatan menyerasikan hubungan nilai-nilai yang terjabarkan di dalam kaidah-kaidah yang mantap dan mengejawantah dan sikap tindak sebagai rangkaian penjabaran nilai tahap akhir, untuk menciptakan, memelihara dan mempertahankan kedamaian pergaulan hidup. Namun apabila penegakan hukum dilihat sebagai suatu proses, dalam hal ini Soerjono Soekanto dengan mengutip Wyne La Farve mengatakan; pada hakekatnya merupakan penerapan diskresi yang menyangkut membuat keputusan yang tidak secara ketat diatur oleh kaidah hukum, akan tetapi mempunyai unsur penilaian. Mengenai penegakan hukum ini Satjipto Rahardjo berpendapat: ${ }^{13}$

"Pada hakekatnya hukum mengandung ide atau konsep-konsep dan dengan demikian boleh digolongkan kepada sesuatu yang abstrak. Ke dalam kelompok

\footnotetext{
${ }^{12}$ Soerjono Soekanto, Faktor-Faktor yang Mempengarubi Penegakan Hukum, Jakarta, Rajawali, 1983, hlm. 2-3.

${ }^{13}$ Satjipto Rahardjo, "Masalah Penegakan Hukum suatu tinjauan sosiologis", Bandung, Sinar Baru, tanpa tahun, hlm. 15 .
} 
yang abstrak ini termasuk ide tentang keadilan, kepastian hukum dan kemamfaatan sosial. Dengan demikian, apabila kita berbicara mengenai penegakan hukum, maka pada hakekatnya berbicara mengenai ide-ide serta konsep-konsep yang nota bene adalah abstrak itu. Dirumuskan secara lain, maka penegakan merupakan suatu usaha untuk mewujudkan ide-ide inilah yang pada hakekatnya hemat saya merupakan hakekat dari penegakan hukum".

Sementara itu menarik pula uraian yang diberikan oleh Soedarto yang menegaskan bahwa perhatian dan penggarapan terhadap perbuatan melawan hukum yang mungkin akan terjadi (onrecht in potentie), itulah yang merupakan penegakan hukum. ${ }^{14}$ Berdasarkan pendapat tersebut di atas, dapat di katakan bahwa, penegakan hukum tidak lain sebagai suatu upaya untuk mewujudkan atau menerapkan ketentuan hukum ke dalam peristiwa-peristiwa yang nyata. Jika berhadapan dengan hukum pidana, maka penegakan hukum pidana berarti upaya untuk mewujudkan atau menerapkan hukum pidana itu ke dalam perbuatanperbuatan kongkrit. Penegakan hukum pidana demikian dapat pula dilihat sebagai suatu upaya penanggulangan kejahatan. ${ }^{15}$

Upaya-upaya penanggulangan kejahatan dengan target menurunkan tingkat kejahatan, memperlihatkan adanya jumlah kejahatan yang terjadi dan kejahatan yang dapat diproses melalui penegakan hukum. Dari pengalaman menunjukkan bahwa, selama upaya penanggulangan kejahatan dilakukan terdapat pula kejahatan yang tidak dapat dituntut yang disebut "undetected crimes" dan "release without prosecution". Adanya realitas kejahatan demikian sehingga tercipta peta kriminal yang meliputi tiga daerah operasional dalam wilayah penegakan hukum yaitu, ${ }^{16}{ }^{1}(1)$ penegakan hukum tidak dapat dilaksanakan secara total (area of no enforcement), (2) diskresi dan syarat penuntutan dalam penegakan hukum (area dicisions not to enforce) dan (3) penuntutan secara nyata yang dapat dilaksanakan dalam penegakan hukum (area of actual enforcement).

Idealnya proses penegakan hukum pada akhirnya akan memberikan perasaan aman, kedamaian dan keadilan bagi semua pihak sehingga kemudian akan mengakhiri atau paling tidak mengurangi pertikaian di antara semua pihak yang berperkara, demikian pula sekaligus mengurangi lajunya tingkat kejahatan. Lembaga peradilan sebagai wadah pelaksanaan proses penegakan hukum bertanggung jawab penuh untuk mengantarkan tercapainya tingkat yang ideal itu. Oleh karena itu,

\footnotetext{
${ }^{14}$ Soedarto, Hukum dan Hukum Pidana, Bandung, Alumni, 1977, hlm. 187.

${ }^{15}$ Barda Nawawi Arif, Beberapa Aspek. Kebijakan Penegakan dan Pengembangan Hukum Pidana, Bandung, PT Citra Aditya Bakti, 1998, hlm 22.

${ }^{16}$ Bambang Poernomo, Pola dasar Teori dan Azas Umum Hukum Acara Pidana, Yogyakarta, Liberty, 1988, hlm. 42.
} 
lembaga pengadilan di dalam melakukan proses penegakan hukum dituntut untuk selalu menghasilkan putusan yang berintikan keadilan. Memang sulit untuk menentukan putusan yang berkeadilan dari suatu pengadilan, apalagi jika keadilan itu dihubungkan dengan berbagai pihak. Boleh saja putusan itu mungkin adil bagi pihak tertentu tapi tidak adil bagi pihak lainnya.

Berkenaan dengan putusan pengadilan ini, patut dipertimbangkan pendapat dari Gustav Radburch, ${ }^{17}$ bahwa suatu putusan pengadilan idealnya harus mengandung idée das recht, yaitu aspek keadilan (gerechtigheit), aspek kepastian hukum (rechtssicherkeit) dan aspek kemanfaatan (rechtmatigkeit). Ketiga Ide hukum ini, bukan sesuatu hal yang mudah jika akan diterapkan ke dalam putusan pengadilan karena tidak menutup kemungkinan adanya ketidak serasian antara tuntutan kepastian hukum di satu sisi dengan tuntutan keadilan masyarakat di sisi lain. Gambaran ini dapat saja terjadi ketika lembaga pengadilan menentukan putusan terhadap perkara yang dihadapi, di mana putusan pengadilan mungkin saja telah memuat tingkat kepastian hukum yang tinggi, akan tetapi putusan tersebut tidak dirasakan adil dan bermanfaat bagi para pencari keadilan. Sebaliknya putusan pengadilan telah memuat dan mencerminkan keadilan dan bermanfaat bagi masyarakat, namun tidak selaras dengan kepastian hukum. Meskipun demikian, ketiga aspek ide hukum tersebut sedapat mungkin menjadi perhatian oleh lembaga peradilan secara proporsional, namun jika terjadi benturan antara ketiganya barangkali akan lebih bijak jika lembaga peradilan tetap mengedepankan dan tetap menjunjung tinggi keadilan masyarakat ketimbang lainnya.

Jika pembicaraan selama ini telah menempatkan pengadilan sebagai lembaga dependen, bukan sebagai lembaga independen (mandiri) khususnya ketika lembaga ini menangani beberapa kasus-kasus tertentu terutama kasus politik, korupsi dan kasus-kasus yang bernilai jutaan rupiah, nampaknya telah berdampak buruk kepada proses penegakan hukum. Lemahnya dan runtuhnya kemandirian pengadilan menjadikan pula proses penegakan hukum menjadi suram. Implikasi ini tetap berlanjut hingga adanya perubahan pada tingkat kemandirian pengadilan. Untuk itu, bagaimana bentuk implikasi kemandirian pengadilan, tergantung kepada sejauh mana perubahan tingkat kemandiran pengadilan. itu sendiri. Bilamana kemandirian

${ }^{17}$ Catatan kuliah dari Sudikno Mertokusumo, di program Pasca Sarjana Ilmu Hukum UGM Ypgyakarta, sebagaimana dikutip oleh Bambang Sutiyoso di dalam Hasil penelitian tentang Kemandirian kekuasaan Kehakiman Dan Implikasinya terhadap Penegakan Hukum, hlm. 48. 
lembaga peradilan tetap terjaga dengan baik, maka arah implikasinya akan menjadikan proses penegakan hukum itupun menjadi baik. Sebaliknya bilamana kemandirian pengadilan itu berada pada tingkat yang buruk, maka arah implikasinya akan menjadikan proses penegakan hukum menjadi terburuk pula.

Berbagai fakta telah menunjukkan bahwa dampak dari ketidak mandirian pengadilan itu, menjadikan proses penegakan hukum sungguh memprihatinkan. Pada awal Orde baru ketika Soeharto mulai memegang tampuk kekuasan secara penuh tahun 1967, Ia menunjukkan komitmen besar bagi penegakan hukum. Ia mengalokasikan anggaran cukup besar bagi bidang ini termasuk melahirkan undangundang baru, memperbaiki kinerja tiga pilar hukum, kehakiman, kejaksaan dan kepolisian. Akan tetapi, situasi ini tidak berlangsung lama. Sebab kemudian, tampak betapa dominannya eksekutif serta demikian lemahnya posisi lembaga yudikatif. Ini terus berlangsung hingga mencapai gradasi sangat parah. ${ }^{18}$

Pada era reformasi lagi-lagi muncul harapan untuk melakukan perbaikan di tubuh lembaga pengadilan, langkah ke arah sana telah dilakukan dengan melakukan perubahan terhadap Undang-Undang Pokok kekuasaan kehakiman Undang-Undang No. 14 Tahun 1970. Langkah ini dilakukan dengan harapan akan berpengaruh pula kepada penegakan hukum yang telah dirasakan sangat parah itu. Namun harapan itupun belum juga terwujud karena pada kenyataannya proses penegakan hukum di negeri yang sering meneriakkan slogan "negara hukum" belum berjalan sebagaimana mestinya.

Untuk mengetahui bagaimana respon masyarakat penegakan hukum di tanah air, menarik mengemukakan hasil jajak pendapat yang dilakukan oleh harian Kompas dan hasilnya telah dimuat di dalam harian ini Rabu 24 Oktober 2001, halaman 8. Jajak pendapat ini dilakukan di 13 ibu kota propinsi terhadap upaya pemerintahan Megawati menegakan hukum ketika pemerintahannya baru berusia tiga bulan. Dari jajak pendapat ini disimpulkan bahwa; Tiga bulan usia kepemimpinan Presiden megawati soekarnoputri belum mampu mengangkat rasa keadilan di masyarakat. Masyarakat menganggap , upaya penegakan hukum di negeri ini dirasakan sebatas impian Dalam jajak pendapat ini, penilaian sempitnya ruang bagi penegakan hukum masih dominan. Mereka menganggap, ruang yang ada hanyalah ruang keberpihakan hukum kepada kelompok yang berkuasa, secara politik maupun ekonomi. Dengan

\footnotetext{
${ }^{18}$ Laporan Akhir Tahun Bidang Hukum dengan judul "Hampir Padam Keinginan Tegakkan Hukum”, Kompas, Kamis tanggal $24-12-1998$.
} 
kata lain, yang berlaku saat ini adalah cengkraman kekuasaan yang sangat kuat di dalam setiap proses penegakan hukum. Demikian beberapa pandangan masyarakat hasil jajak pendapat Kompas berkaitan dengan penegakan hukum itu.

Penegakan hukum yang demikian itu hanya menyentuh pada masyarakat bawah, masyarakat yang tidak terkait dengan akar kekuasaan, masyarakat miskin dan buta hukum. Ketika mereka melakukan pelanggaran hukum, maka secepat itu pula penegak hukum melakukan proses hukum hingga dalam waktu yang relatif singkat, pelakunya sudah harus mendekam di dalam penjara. Berbeda ketika berhadapan dengan upper power level (pejabat tinggi publik) maupun upper economic level (konglomerat) atau di antara upper power level, maka tampak adalah suatu diskriminasi hukum yang sangat dominan, sehingga isu pemberantasan korupsi tetap tidak tersentuh hukum mengingat pihak yang terlibat tersebut adalah bagian dari level politik dan ekonomi yang berstatus beyond the law ${ }^{19}$ Kalaupun mereka akhirnya diajukan ke sidang pengadilan itupun hanya sebuah sandiwara yang akhirnya putusannya sudah dapat diduga yakni bebas atau pidana yang jauh dari rasa keadilan.

Kemandirian pengadilan menjadi keharusan bagi setiap negara yang mengklaim dirinya sebagai negara hukum karena pada negara yang memiliki kemandirian pengadilannya itulah yang mampu mengantarkan negara itu melaksanakan hukum secara konsekuen. Pengalaman sejarah telah membuktikan, dan pengalaman ini tidak hanya di dalam negeri tetapi juga di berbagai negara bahwa, jika mengabaikan kemandirian pengadilan maka proses penegakan hukum akan macet dan kalaulah toh masih berjalan, maka dasar kepentingannya bukan untuk keadilan melainkan demi kepentingan tertentu. Oleh karena itu bukannya sekedar membutuhkan teriakan dan pengakuan sebagai negara hukum, karena sekalipun setiap saat mengklaim dan meneriakkan negara hukum, namun jika perangkat dan lembaga hukumnya tidak mendukung, terutama kepada kuatnya jaminan kemandirian pengadilan, maka teriakan itu tetap sebagai slogan bagaikan tong kosong nyaring bunyinya.

Apakah mungkin kemandirian pengadilan dapat diwujudkan? Banyak orang yang merasa pesimis akan hal itu, karena bagi mereka kemandirian memang sulit untuk diwujudkan apalagi dengan kondisi seperti sekarang ini di mana budaya korup

\footnotetext{
${ }^{19}$ Indrianto Seno Adji, "Prespektif Penegakan Hukum yang semu”, Kompas, 31 Desember 2001 hlm. 4.
} 